\title{
Presence of Symbiodinium spp. in macroalgal microhabitats from the Southern Great Barrier Reef
}

\author{
D. E. Venera-Ponton ${ }^{1}$, G. Diaz-Pulido ${ }^{2}$, M. Rodriguez-Lanetty ${ }^{3}$, O. Hoegh-Guldberg ${ }^{4}$
}

${ }^{1}$ Instituto de Investigaciones Tropicales, Universidad del Magdalena, Carrera 32 \# 22-08, Santa Marta, Colombia, South America

${ }^{2}$ Griffith School of Environment, Nathan Campus, Griffith University, 170 Kessels Road, Brisbane, Nathan, Queensland 4111, Australia

${ }^{3}$ Integrative Marine Genomics and Symbiosis Laboratory, Department of Biology, The University of Louisiana at Lafayette, PO Box 42451, Lafayette, LA 70504, USA

${ }^{4}$ Centre for Marine Studies and Australian Research Council Centre of Excellence for Coral Reef Studies, The University of Queensland, St Lucia, Brisbane, Queensland 4072, Australia

Corresponding author: Dagoberto E. Venera-Ponton, Instituto de Investigaciones Tropicales, Universidad del Magdalena, Carrera 32 \# 22-08, Santa Marta, Colombia, South America. Fax: +57 (5) 4301292 Ext. 273, Email: dagovenera@gmail.com.

Keywords: Macroalgal-associated Symbiodinium, Symbiodinium clade C, Coral-algal interactions, Coral reef macroalgae 


\begin{abstract}
Coral reefs are highly dependent on the mutualistic symbiosis between reef-building corals and dinoflagellates from the genus Symbiodinium. These dinoflagellates spend part of their life cycle outside the coral host and in the majority of the cases have to re-infect corals each generation. While considerable insight has been gained about Symbiodinium in corals, little is known about the ecology and biology of Symbiodinium in other reef microhabitats. This study documents Symbiodinium associating with benthic macroalgae on the Southern Great Barrier Reef, including some Symbiodinium that are genetically close to the symbiotic strains from reef-building corals. It is possible that some of these Symbiodinium were in hospite, associated to soritid foraminifera or ciliates; nevertheless, the presence of Symbiodinium C3 and C15 in macroalgal-microhabitats may also suggest a potential link between communities of Symbiodinium associating with both coral hosts and macroalgae.
\end{abstract}




\section{Introduction}

Coral reefs provide goods and services that are valuable to many millions of people throughout tropical coastal areas (Moberg and Folke 1999). Reef-building corals (Order Scleractinia) are central to coral reefs, providing much of the productivity and calcification required to build these ecosystems (Muller-Parker and D’Elia 1997). These organisms form mutualistic symbioses with dinoflagellates Symbiodinium spp. which provide corals with abundant photosynthetic energy, enabling them to lay down copious quantities of calcium carbonate and thrive in nutrient-poor environments (Muller-Parker and D’Elia 1997).

Unfortunately, coral reefs are facing a number of serious threats and are severely in decline (Hughes et al. 2003; Hoegh-Guldberg et al. 2007). These threats are arising from declining coastal water quality and over-fishing, as well as warming and acidification of the world's oceans as a result of rising atmospheric carbon dioxide and other greenhouse gases. Rapid changes in water temperature, for example, have caused sudden breakdown of the mutualistic endosymbiosis of corals and dinoflagellates (mass coral bleaching; HoeghGuldberg 1999). Mass bleaching events have had a serious impact on coral reefs throughout the world since 1979 when they were first reported in the literature. Our current understanding of the temperature tolerance of corals suggest that projected sea temperatures will soon approach and exceed the known thermal thresholds to reef-building corals, putting in doubt the future of coral dominated reef systems (Hoegh-Guldberg 1999; Hoegh-Guldberg et al. 2007).

Due to the potentially devastating impacts of climate change on reef-building corals and coral reefs in general, considerable attention has been given to the physiology and ecology of coral-dinoflagellate symbioses, particularly on the factors and mechanisms that cause its maintenance or breakdown (see Lesser 1997; Ralph et al. 2001). Other studies have focused on the diversity, phylogeny (e.g., Carlos et al. 1999; Lajeunesse 2001; Santos et al. 
2002; Rodriguez-Lanetty 2003; Coffroth and Santos 2005), biogeography, community ecology (e.g., Rodriguez-Lanetty et al. 2001; LaJeunesse et al. 2003; Sampayo et al. 2007) and the acquisition of Symbiodinium (e.g., Lewis and Coffroth 2004; Pasternak et al. 2006; Gomez-Cabrera et al. 2008), which forms an important base for understanding the dynamics of coral-dinoflagellates endosymbiosis. By contrast, however, studies exploring the biology and ecology of Symbiodinium in other reef microhabitats are rare.

Studies on the diversity of Symbiodinium have revealed that it is a very diverse group with at least nine distinct genetic clades, A-I (Baker 2003; Coffroth and Santos 2005; Stat et al. 2006; Pochon and Gates 2010). Clades A, B, C and D are the predominant symbionts of scleractinians while clade E is found in sea anemones and clades F, G and H are common in foraminifera (Baker 2003; Coffroth and Santos 2005; Stat et al. 2006). Clades C and D can also inhabit in foraminifera while clades F and G sometimes can be found, although rarely, in scleractinians (Rodriguez-Lanetty et al. 2002; Pochon et al. 2004, 2007; Pochon and Pawlowski 2006). Clade I was recently discovered and establishes symbiosis with foraminifera (Pochon and Gates 2010). Clade C has a very wide range of hosts, which include a marine ciliate (Lobban et al. 2002) in addition to scleractinian and foraminiferan hosts (Pochon et al. 2001, 2004, 2007; Pochon and Pawlowski 2006).

Within each Symbiodinium clade there is even more diversity grouped in subclade types (Baker 2003; Coffroth and Santos 2005; Stat et al. 2006). Clade C is the most diverse Symbiodinium lineage in the Pacific with more than 100 subclade types (LaJeunesse et al. 2003; Pochon et al. 2004; Sampayo et al. 2007). Some of these subclade types can be identified with several molecular markers including large subunit ribosomal DNA (LSUrDNA) and internal transcriber spacers (ITS) (LaJeunesse et al. 2003; Sampayo et al. 2009). Comprehensive reviews of Symbiodinium diversity can be found in LaJeunesse (2001), Baker (2003), LaJeunesse (2005), Coffroth and Santos (2005), and Stat et al. (2006). 
Symbiodinium spend part of their life cycle as free-living Gymnodinium-like dinoflagellates, and in some cases re-infect corals each generation (Gomez-Cabrera et al. 2008; Adams et al. 2009). Despite the fairly extensive information on Symbiodinium as coral symbionts, there are a number of key questions surrounding these organisms. For example, our understanding of the importance of other habitats that they use, their population dynamics through space and time, and how they are taken back into host corals cells remain incomplete. This said, there are a growing number of studies indicating that Symbiodinium are present in the seawater column (Gou et al. 2003; Coffroth et al. 2006; Manning and Gates 2008; Pochon et al. 2010), interstitial water of sands (Carlos et al. 1999; Hirose et al. 2008; Pochon et al. 2010), rocky reefs and seagrasses (Coffroth et al. 2006) and on benthic macroalgae (Porto et al. 2008). Moreover, it has been demonstrated that both pelagic and benthic Symbiodinium can establish symbiosis with corals (Lewis and Coffroth 2004; Coffroth et al. 2006; Adams et al. 2009), although some genotypes are apparently unable to establish symbiosis (Coffroth et al. 2006; Pochon et al. 2010).

Macroalgae are the most abundant benthic component of many coral reefs (Wilkinson 2004; Diaz-Pulido 2008). Benthic macroalgae release organic substances (Khailov and Burlakova 1969; Wada et al. 2007), which may promote the establishment of microbial communities on their surfaces (Armstrong et al. 2000; Longford et al. 2007). Also many epiphytic dinoflagellates show a distinct preference for macroalgal hosts which may release growth-stimulating algal compounds or provide large surface areas for attachment (Morton and Faust 1997; Parson and Preskitt 2007). Consequently, there is a strong possibility that macroalgae may serve as an important reservoir for Symbiodinium within coral reef habitats.

Porto et al. (2008) found Symbiodinium associated to the benthic macroalgae Halimeda spp., Lobophora variegata, Amphiroa spp., Caulerpa spp. and Dictyota spp. in Caribbean coral reefs. However, the potential role of macroalgae as a source of Symbiodinium 
to infect reef-building corals still remains an important unknown. This study explores the presence, identity and potential relationship of macroalgal-associated Symbiodinium to those associated with reef-building corals on the southern Great Barrier Reef. Specifically, this study evaluates whether the Symbiodinium subclades found in macroalgal microhabitats are the same as those found in reef building corals.

\section{Materials and Methods}

\section{Sample Collection}

Seawater samples were collected from macroalgal microhabitats and sediments in coral reefs from the Heron and Keppel Islands on the Southern Great Barrier Reef, Australia (Fig. 1). Four types of samples were taken:

1) Complete sections of macroalgal thalli and cyanobacterial mats were collected with associated seawater, taking care to avoid pieces of the substrate to which the macroalgae were attached.

2) Crustose coralline algae (CCA) and tiny algal turfs were collected with associated seawater and substrates, which were broken off from the calcareous matrix.

3) Sediments were collected with associated seawater.

4) Seawater from the interstitial space of sediments and from the surface of algal turfs or CCAs was collected with $50 \mathrm{ml}$ syringes.

Field collection was made with $0.5 \mathrm{~L}, 1 \mathrm{~L}$ and $2 \mathrm{~L}$ plastic bags, depending on the amount of material, and some samples needed more than one $2 \mathrm{~L}$ bag. A total of 33 macroalgal samples (including one cyanobacterial sample and four CCA samples) and four sediment samples were collected (Table 1). Two sediment samples were collected near sanddwelling algal turfs (one from 2 m deep in Heron Island and the another from $12 \mathrm{~m}$ deep in Keppel Islands) while two others were collected away from macroalgae. 
Each sample was vigorously shaken after collection and filtered through a $200 \mu \mathrm{m}$ pore-size mesh. Samples were then filtered again through a $0.5 \mu \mathrm{m}$ millipore GFC using a vacuum pump (Capex 8C). The differential pressure in the filter was about 720 mbar. To preserve the potential Symbiodinium DNA content, each filter paper was immersed in $20 \%$ Dimethylsulfoxide (DMSO) within a dark flask (covered with aluminium foil) and transported to the Centre for Marine Studies at The University of Queensland where the samples were stored in a freezer $\left(-20^{\circ} \mathrm{C}\right)$ until the DNA extraction.

\section{DNA Extraction}

In order to remove the DMSO, which is undesirable for the following procedures, each filter paper was cut in smaller pieces and rinsed in DNA-Buffer [50 mM EDTA (pH 8.0), 0.4 $\mathrm{M} \mathrm{NaCl}$. DNA was then isolated from filter papers with the Phenol-Chloroform method, following the protocol of Vidal et al. (2002). This protocol was originally designed to improve the DNA extraction from CCA but also enhanced DNA extractions from any alga. This protocol is desirable for samples with low or indeterminate amounts of DNA. The steps involved in this protocol that were intended for cleaning up and grinding CCAs were skipped, given the different material. Consequently, the isolation of the DNA was started by transferring pieces of each filter paper to a $2 \mathrm{ml}$ eppendorf tube containing $700 \mu \mathrm{l}$ of extraction buffer [4 M Urea, 250 mM Tris-HCl (pH 8.0), 250 mM NaCl, 50 mM EDTA (pH 8.0), 5\% 2-Mercaptoethanol, 2\% Sodium dodecyl sulphate] and $15 \mu \mathrm{l}$ of Proteinase K (20 mg $\mathrm{ml}^{-1}$ ). The final dried pellet was re-suspended in $50 \mu \mathrm{l}$ of TE buffer [10 mM Tris-HCL (pH 8.0), 1 mM EDTA]. The quality and concentration of the extracted DNA was analyzed through gel electrophoresis and NanoDrop spectrophotometry (Thermo Scientific, Wilmington, USA); samples with less than $15 \mathrm{ng} \mathrm{Hl}^{-1}$ of DNA were concentrated through vacuum centrifuging at $37^{\circ} \mathrm{C}$ for $20 \mathrm{~min}$. 


\section{PCRs, cloning and sequencing}

The variable domains D1 and D2 of 28S large subunit ribosomal DNA (28SLSUrDNA) were used given that they provide moderate resolution of Symbiodinium to the subclade level (e.g., LaJeunesse et al. 2003; Sampayo et al. 2009). D1 and D2 28S-LSUrDNA of potential Symbiodinium were amplified using the Toha PCR primer set (see RodriguezLanetty et al. 2001): forward (Toha F): 5'-CCT CAG TAA TGG GGA ATG AAC A-3’ and reverse (Toha R): 5'-CCT TGG TCC GTG TTT CAA GA-3’. All PCR reactions contained $>15 \mathrm{ng}$ of template DNA, 1X PCR buffer, $2.5 \mathrm{mM} \mathrm{MgCl}_{2}, 0.2 \mathrm{mM}$ of each primer, $200 \mathrm{mM}$ dNTP and $0.1 \mathrm{mM}$ Taq polymerase platinum, and filter-sterilized water for a total volume of $20 \mu \mathrm{l}$. The PCR conditions involved an initial denature period of $2 \mathrm{~min}$ at $94{ }^{\circ} \mathrm{C}$, followed by 30 cycles of $15 \mathrm{~s}$ at $94{ }^{\circ} \mathrm{C}, 15 \mathrm{~s}$ at $60{ }^{\circ} \mathrm{C}, 60 \mathrm{~s}$ at $72{ }^{\circ} \mathrm{C}$ and a final extension period of $5 \mathrm{~min}$ at $72{ }^{\circ} \mathrm{C}$. After the PCR, the samples were held at $4{ }^{\circ} \mathrm{C}$. The PCR products were purified with the QIAquick PCR purification kit, QIAGEN.

The different 28S-LSUrDNA fragments contained at each sample were separated and cloned in TOP TEN cells (Invitrogen, AU) by using the pGEM-T Vector System, following the manufacturer's protocol. 32 ng of PCR products (3:1 insert:vector molar ratio) were used for the ligation. Four clones per library were PCR-amplified at their 28S-LSUrDNA (as above), purified with QUIAquick (as above), and sent to the Australian Genomic Research Facility for sequencing. Unfortunately, because of time limitations, it was not possible to sequence more clones per library.

\section{Data Analysis}

Amplified and sequenced DNA was compared to Symbiodinium sequences using the Basic Local Alignment Search Tool (BLAST; Altschul et al. 1990) and the GenBank 
database. Those Symbiodinium sequences that showed the highest similarity scores with the resulting sequences and E-Values $<\mathrm{e}^{-10}$ were downloaded. 28S-LSUrDNA sequences of the Symbiodinium subclade types C1, C1b, C3, C15, C17, C21 and C27, described and reported by LaJeunesse et al. (2003) were also downloaded. Additionally, at least two 28S-LSUrDNA sequences of the Symbiodinium clades A, B, C, D, E, F and H were also downloaded.

All resulting and GenBank sequences were aligned using ClustalX 2.0. Sequences that did not belong to Symbiodinium (according to the BLAST search) were not aligned. Phylogenetic inference analyses were performed with the aligned sequences to determine the phylogenetic position of Symbiodinium isolates obtained in this study (Table 2). Sequences that belonged to Symbiodinium, according to the BLAST analyses but had too much baseline noise were excluded from the phylogenetic analyses. The phylogenetic analyses were then performed with the Maximum-Parsimony and Maximum-Likelihood methods, using the best fit model of evolution ( $\operatorname{TrN}+\mathrm{G})$ according to jModeltest (Posada 2008). These analyses were run using the beta version of the PAUP 4.0 software (Sinauer Associates, Massachusetts, USA). Gaps were treated as a fifth character state, starting trees were obtained via stepwise addition, sequence addition was simple, and it was used the tree-bisection-reconnection (TBR) branch-swapping algorithm to find the best tree(s). If more than one tree were found, then the 50\% Majority-Rule Consensus Tree was calculated. 500 bootstrap replicates were performed for each analysis.

\section{Results}

The 28S-LSUrDNA sequences from a total of 25 samples were amplified. Of these, 24 were cloned while the remaining sediment sample was directly sequenced and identified as a non-symbiotic dinoflagellate. Among 96 clones that were sequenced (four clones per library), 21 were identified as belonging to Symbiodinium ( $22 \%$ of clones sequenced) and 16 as non- 
symbiotic dinoflagellates. The remaining 59 clones were either of poor-quality or had sequences similar to platyhelminthes or non-symbiotic ciliates (e.g., Paramecium). Symbiodinium were associated with samples from the green macroalgae Chlorodesmis fastigiata, Halimeda opuntia and $H$. discoidea, the red macroalgae Hypnea spinella and $H$. pannosa, Laurencia intricata and Asparagopsis taxiformis, the brown macroalgae Padina sp. and Lobophora variegata, and algal turfs (see Fig. 2, Tables 1 and 2).

Non-symbiotic dinoflagellates (e.g., Gyrodinium, Karlodinium and Prorocentrum) were associated with samples from Porolithon onkodes (CCA), cyanobacterial mats, sediments and also Halimeda discoidea, Hypnea pannosa, Laurencia intricata, Asparagopsis taxiformis, Lobophora variegata and algal turfs. All Symbiodinium found in macroalgal microhabitats belonged to the clade $\mathrm{C}$ and were similar to strains of Symbiodinium that establish symbiosis with corals, according to the BLAST search (score $>920$; E-value $=0.0$; similarity >98\%) (Table 3). Only Dc11 from Lobophora variegata (score $=720$ ) showed a score $<920$ in the BLAST search.

The phylogenetic analyses revealed that all Symbiodinium isolated from macroalgal microhabitats belonged to the clade C (Fig. 3). Interestingly, however, they are spread between at least two subclades. Strain Dc58, isolated from Hypnea pannosa, grouped with Symbiodinium C15 (a strain that normally associates with the coral Porites; LaJeunesse et al. 2003); strains Dc25, Dc54, Dc60, Dc70, Dc72 grouped with Symbiodinium C3 (a strain associating with Acropora, Favia and a large number of other coral genera; LaJeunesse et al. 2003). Dc30 grouped with Symbiodinium C17 (a strain that associates with Montipora; LaJeunesse et al. 2003) but with a very low bootstrap support (<50\%). Strains Dc1, Dc2, Dc3, Dc4, Dc6, Dc8, Dc15, Dc21, Dc27, Dc68, Dc82, Dc88 did not clearly fall within any subclade. Sequences Dc36 and Dc11 were not included in the phylogenetic analyses because they had too much baseline noise. Phylogenetic positions of macroalgal-associated 
Symbiodinium did not vary much among trees generated by Maximum-Parsimony and Maximum-Likelihood. The tree inferred by Maximum-Parsimony (data not shown) was a consensus (50\% majority rule) of ten trees. Subclades C3 and C15 were supported with bootstrap values of $96 \%$ and $88 \%$, respectively.

\section{Discussion}

The present study has found evidence that macroalgae may serve as potential microhabitats for Symbiodinium spp. when they are outside their cnidarian hosts. Symbiodinium were found associated with macroalgae from a wide variety of depths and sites (Heron-reef flat, Heron- $4^{\text {th }}$ point, Keppel-Middle Island, Keppel-Halfway Island) on the Southern Great Barrier Reef. Symbiodinium were associated with a wide variety of macroalgal forms that included foliose (Padina sp., Lobophora variegata), turfing filamentous (mixed algal turfs), non-turfing filamentous (Chlorodesmis fastigiata), calcareous articulated (Halimeda spp.) and corticated macrophytes (Laurencia intricata, Hypnea spp., Asparagopsis taxiformis). Symbiodinium also associated with a range of macroalgal phyla including Chlorophyta (green algae: Chlorodesmis fastigiata, Halimeda spp.), Ochrophyta (Phaeophyceae, brown algae: Lobophora variegata, Padina sp.) and Rhodophyta (red algae: Asparagopsis taxiformis, Hypnea spp., Laurencia intricata).

While the present study did not find any Symbiodinium associated with Cyanobacteria, or the red macroalgae Porolithon onkodes, Plocamium sp. and Peyssonnelia sp., the finding of other dinoflagellates that were associated with Porolithon onkodes and Cyanobacteria suggest that it would be too early to rule out these macroalgae as potential microhabitats for Symbiodinium. Moreover, the presence of Symbiodinium associated to Plocamium sp. and Peyssonnelia sp. was evaluated on few samples per species (see Table 1), thereby limiting the chance of finding Symbiodinium. 
Symbiodinium was not found to be associated with sediments on the southern Great Barrier Reef. The presence of Symbiodinium in reef sediments, however, has been demonstrated by previous studies in the Caribbean Sea (Porto et al. 2008) and Pacific Ocean (Carlos et al. 1999; Hirose et al. 2008; Adams et al. 2009; Pochon et al. 2010). Previous studies have emphasized the limitations of directly extracting DNA from sediments, especially the action of sediment-associated substances interfering with the DNA extraction process (Steffan et al. 1988; Lovell and Piceno 1994; Gray and Herwig 1996). For that reason, studies reporting sediment-associated Symbiodinium have generally used direct isolation and culture of potential candidates before molecular identification (e.g., Carlos et al. 1999; Hirose et al. 2008). Given that the present study did not use direct isolation and culture, it would be premature to rule out the presence of Symbiodinium in sediments on the Southern Great Barrier Reef.

Previous studies of free-living Symbiodinium have shown contrasting effectiveness at recovering Symbiodinium sequences from clone libraries. Littman et al. (2008) were 1\% efficient (four Symbiodinium amongst 319 clones) using 18S rDNA while Manning and Gates (2008) were $>90 \%$ efficient using a hypervariable region of 23S (see Table 2 of Manning and Gates 2008). A rapid comparison of this study with these studies suggests that the recovery of Symbiodinium from clone libraries was moderately efficient here (22\%; 21 Symbiodinium amongst 96 clones). The very low efficiency found by Littman et al. (2008) may be explained by the fact that their genetic analyses were employed on sediments samples where molecular analyses have limitations as explained above.

Most Pacific corals harbor Symbiodinium clade C although most Caribbean corals, on the other hand, are associated with Symbiodinium clades B, with significant numbers of Caribbean corals also having clades A and C (Baker et al. 1997; LaJeunesse et al. 2003). The same biogeographic distribution was also found in Symbiodinium from the water column by 
Manning and Gates (2008). Interestingly, the present study only found Symbiodinium clade C to be associated with macroalgae in the Southern Great Barrier Reef while Porto et al. (2008) found a large range of Symbiodinium clades (A, B and C) associated to benthic macroalgae in Caribbean coral reefs. Nevertheless, it is likely that the diversity of macroalgal-associated Symbiodinium was underestimated in this study as it explored as many macroalgal microhabitats as possible but the number of sequenced clones per library was low. It is possible that more Symbiodinium clades/subclades appeared if more clones per library were sequenced.

Subclades Dc25, Dc54, Dc60, Dc70 and Dc72 from the present study grouped with Symbiodinium C3 (96\% bootstrap support; Figs. 3, Table 3). This is interesting given that C3 is a generalist subclade which establishes symbioses with many coral species in Pacific and Caribbean coral reefs (LaJeunesse et al. 2003; Table 3) as well as some foraminifera (Pochon et al. 2007). The occurrence of this strain in several samples illustrates the potential importance of macroalgae as a source of Symbiodinium for a huge number of coral species. Strain Dc58 grouped with Symbiodinium C15 (88\% bootstrap support) which associates with thermally tolerant corals (Porites spp. and Montipora digitata; LaJeunesse et al. 2003) and foraminifera (Pochon et al. 2004). It is believed that thermal tolerance of those hosts is given by Symbiodinium C15. Red macroalgae were the only macroalgal phylum that grouped with symbiotic strains of Symbiodinium (i.e., C3 and C15), while green and brown macroalgae did not clearly associate to any subclade. Given the fact that this pattern may change if more clones per library were sequenced, it will require verification in follow-up studies.

It is possible that some macroalgal-associated Symbiodinium found in the present study were in hospite, associated to soritid foraminifera or macroscopic ciliates. The latter have been reported to harbour Symbiodinium clade C and inhabit macroalgal microhabitats (Pochon et al. 2004, 2007; Lobban et al. 2002, Pochon and Pawlowski 2006). It is also 
possible that some Symbiodinium came from symbiotic larvae; however, the collection of samples occurred in August, which is two months before the coral spawning in the Great Barrier Reef (Willis et al. 1985; Babcock et al. 1986). Symbiodinium C15 and C3 have been previously isolated from both corals and foraminifera (Pochon et al. 2004, 2007; Pochon and Pawlowski 2006); thus, it is uncertain whether the macroalgal-associated Symbiodinium C15 and C3 found here were free-living or foraminifera-associated (although careful stereomicroscopic examination of the filter papers with the samples did not find soritid foraminifera). Nevertheless, the presence of Symbiodinium C3 and C15 in Pacific macroalgalmicrohabitats may also suggest, with limitations, a potential close link between coral zooxanthellae and macroalgal-associated Symbiodinium populations/communities.

It is interesting to consider why Symbiodinium may associate with macroalgae. Porto et al. (2008) suggest that Symbiodinium associate to benthic macroalgae because their intricate branching networks with high surface-to-volume ratios provide substrate, light attenuation and refuge for Symbiodinium. On the other hand, studies on other epiphytic dinoflagellates suggest that they associate with some benthic macroalgae primarily because of the large amount of surface area upon which to attach (Parson and Preskitt 2007) and possibly because they release organic substances that stimulate the growth and provide other resources for epiphytic dinoflagellates (Morton and Faust 1997). Given that the water column associated with coral reefs tends to be nutrient poor, organic substances along with inorganic nutrients released by benthic macroalgae (Khailov and Burlakova 1969; Wada et al. 2007) may play a critical role in the survival of Symbiodinium outside their coral hosts. This idea requires further exploration to establish the relative importance of these macroalgal organic and inorganic compounds for the survival of Symbiodinium.

In conclusion, the present study has shown that Symbiodinium are spread among several macroalgal taxa and functional groups on the Southern Great Barrier Reef. Some of 
these Symbiodinium may be in hospite within foraminifera or ciliates; however, the presence of Symbiodinium C3 and C15 in macroalgal-microhabitats may also suggest, with limitations, a potential close link between coral zooxanthellae and macroalgal-associated Symbiodinium communities, and a continuum between symbiotic and environmental Symbiodinium populations. This study has implications for the role of other reef organisms and habitats as potential reservoirs for the symbionts that inhabit reef-building corals. A more complete description of these potential reservoirs is important if we are to continue to improve our understanding of the all-important mutualistic symbiosis between corals and dinoflagellates.

\section{Acknowledgements}

Thanks to M. Gomez-Cabrera, E. Sampayo, N. Rosic and C. Reymond for their help during the laboratory work. Thanks to T. Ridgway and S. Dunn for methodological suggestions. Thanks to C. Arango for her valuable help in the phylogenetic analyses. Thanks to K. Dunn for helping at the Heron Island Research Station. This work was supported by an Australian Research Council grant to OHG, Great Barrier Reef Research Foundation (www.barrierreef.org) and the Reef and Rainforest Research Centre (www.rrrc.org.au).

\section{References}

Adams LM, Cumbo VR, Takabayashi M (2009) Exposure to sediment enhances primary acquisition of Symbiodinium by asymbiotic coral larvae. Mar Ecol Prog Ser 377:149156

Altschul SF, Gish W, Miller W, Myers EW, Lipman DJ (1990) Basic local alignment search tool. J Mol Biol 215:403-10

Armstrong E, Rogerson A, Leftley JW (2000) The abundance of heterotrophic protists associated with intertidal seaweeds. Estuar Coast Shelf Sci 50:415-424

Babcock RC, Bull GD, Harrison PL, Heyward AJ, Oliver JK, Wallace CC, Willis BL. (1986) Sychronous spawning of 105 scleractinian coral species on the Great Barrier Reef. Mar Biol 90:379-394

Baker AC (2003) Flexibility and specificity in coral-algal symbiosis: diversity, ecology and biogeography of Symbiodinium. Annu Rev Ecol Syst 34:661-689

Baker AC, Rowan R, Knowlton N (1997) Diversity of symbiotic dinoflagellates 
(Symbiodinium) in scleractinian corals of the Caribbean and eastern Pacific. Proc 8th Int Coral Reef Symp 2:1301-1306

Carlos AA, Baillie BK, Kawachi M, Maruyama T (1999) Phylogenetic position of Symbiodinium (Dinophyceae) isolates from tridacnids (Bivalvia), cardiids (Bivalvia), a sponge (Porifera), a soft coral (Anthozoa), and a free-living strain. J Phycol 35:10541062

Coffroth MA, Santos SR (2005) Genetic diversity of symbiotic dinoflagellates in the genus Symbiodinium. Protist 156:19-34

Coffroth MA, Lewis CF, Santos SR, Weaver JL (2006) Environmental populations of symbiotic dinoflagellates in the genus Symbiodinium can initiate symbioses with reef cnidarians. Curr Biol 16:R985-R987

Diaz-Pulido G (2008) Macroalgae. In: Hutchings P, Kingsford M, Hoegh-Guldberg O (eds) The Great Barrier Reef: biology, environment and management. CSIRO Publishing, Springer, Collingwood, Australia, pp 145-155

Garcia-Cuetos L, Pochon X, Pawlowski J (2004) Molecular evidence for host-symbiont specificity in soritid foraminifera. Protist 156:399-412

Gomez-Cabrera MD, Ortiz JC, Loh WKW, Ward S, Hoegh-Guldberg O (2008) Acquisition of symbiotic dinoflagellates (Symbiodinium) by juveniles of the coral Acropora longicyathus. Coral Reefs 27:219-226

Gou WL, Sun J, Li XQ, Zhen Y, Xin ZY, Yu ZG, Li RX (2003) Phylogenetic analysis of a free-living strain of Symbiodinium isolated from Jiaozhou Bay, PR China. J Exp Mar Biol Ecol 296:135-144

Gray JP, Herwig RP (1996) Phylogenetic analysis of the bacterial communities in marine sediments. Appl Environ Microbiol 62 (11):4049-4059

Hirose M, Reimer JD, Hidaka M, Suda S (2008) Phylogenetic analyses of potentially freeliving Symbiodinium spp. isolated from coral reef sand in Okinawa, Japan. Mar Biol 155:105-112

Hoegh-Guldberg O (1999) Climate change, coral bleaching and the future of the world's coral reefs. Mar Freshw Res 50:839-866

Hoegh-Guldberg O, Mumby PJ, Hooten AJ, Steneck RS, Greenfield P, Gomez E, Harvell CD, Sale PF, Edwards AJ, Caldeira K, Knowlton N, Eakin CM, Iglesias-Prieto R, Muthiga N, Bradbury RH, Dubi A, Hatziolos ME (2007) Coral reefs under rapid climate change and ocean acidification. Science 318:1737-1742

Hughes TP, Baird AH, Bellwood DR, Card M, Connolly SR, Folke C, Grosberg R, HoeghGuldberg O, Jackson JBC, Kleypas J, Lough JM, Marshall P, Nystrom M, Palumbi SR, Pandolfi JM, Rosen B, Roughgarden J (2003) Climate change, human impacts, and the resilience of coral reefs. Science 301:929-933

Khailov KM, Burlakova ZP (1969) Release of dissolved organic matter by marine seaweeds and distribution of their total organic production to inshore communities. Limnol Oceanogr 14:521-527

LaJeunesse TC (2001) Investigating the biodiversity, ecology, and phylogeny of endosymbiotic dinoflagellates in the genus Symbiodinium using the its region: In search of a "species" level marker. J Phycol 37:866-880

LaJeunesse TC (2005) "Species" radiations of symbiotic dinoflagellates in the Atlantic and Indo-Pacific since the Miocene-Pliocene transition. Molecular Biology and Evolution 22:570-581

LaJeunesse TC, Loh WKW, Van Woesik R, Hoegh-Guldberg O, Schmidt GW, Fitt WK (2003) Low symbiont diversity in Southern Great Barrier Reef corals, relative to those of the Caribbean. Limnol Oceanogr 48:2046-2054

Lesser MP (1997) Oxidative stress causes coral bleaching during exposure to elevated 
temperatures. Coral Reefs 16:187-192

Lewis CL, Coffroth MA (2004) The acquisition of exogenous algal symbionts by an octocoral after bleaching. Science 304:1490-1492

Littman RA, Van Oppen MJH, Willis B (2008) Methods for sampling free-living Symbiodinium (zooxanthellae) and their distribution and abundance at Lizard Island (Great Barrier Reef). J Exp Mar Biol Ecol 364:48-53

Loh WKW, Carter D, Hoegh-Guldberg O (1998) Diversity of Symbiodinium from scleractinian corals of One Tree Island (The Great Barrier Reef). Proceedings of the Australian Coral Reef Society 75th anniversary conference:141-150

Lobban CS, Schefter M, Simpson AGB, Pochon X, Pawlowski J, Foissner W (2002) Maristentor dinoferus n. gen., n. sp., a giant heterotrich ciliate (Spirotrichea: Heterotrichida) with zooxanthellae, from coral reefs of Guam, Mariana Islands. Mar Biol 140:411-423

Longford SR, Tujula NA , Crocetti GR , Holmes AJ , Holmstrom C , Kjelleberg S , Steinberg PD , Taylor MW (2007) Comparisons of diversity of bacterial communities associated with three sessile marine eukaryotes. Aquat Microb Ecol 48:217-229

Lovell CR, Piceno Y (1994) Purification of DNA from estuarine sediments. J Microbiol Methods 20:161-174

Manning MM, Gates RD (2008) Diversity in populations of free-living Symbiodinium from a Caribbean and Pacific reef. Limnol Oceanogr 53:1853-1861

Moberg F, Folke C (1999) Ecological goods and services of coral reef ecosystems. Ecol Econ 29 (2):215-233

Moestrup O, Daugbjerg N (2007) On dinoflagellate phylogeny and classification. In: Brodie J, Lewis J (eds) Unravelling the algae: the past, present, and future of algal systematics. CRC Press, Taylor \& Francis Group, Boca Raton, pp 215-230

Morton SL, Faust MA (1997) Survey of toxic epiphytic dinoflagellates from the Belizean barrier reef ecosystem. Bull Mar Sci 61:899-906

Muller-Parker G, D'Elia CF (1997) Interactions between corals and their symbiotic algae. In: Birkeland C (ed) Life and death of coral reefs. Chapman and Hall, New York, pp 96112

Parson ML, Preskitt LB (2007) A survey of epiphytic dinoflagellates from the coastal waters of the island of Hawai'i. Harmful Algae 6:658-669

Pasternak Z, Blasius B, Abelson A, Achituv Y (2006) Host-finding behaviour and navigation capabilities of symbiotic zooxanthellae. Coral Reefs 25:201-207

Pochon X, Pawlowski J (2006) Evolution of the soritids-Symbiodinium symbiosis. Symbiosis 42:77-88

Pochon X, Gates RD (2010) A new Symbiodinium clade (Dinophyceae) from soritid foraminifera in Hawai'i. Mol Phyl Evol 56:492-497

Pochon X, LaJeunesse TC, Pawlowski J (2004) Biogeographic partitioning and host specialization among foraminiferan dinoflagellates symbionts (Symbiodinium; Dinophyta). Mar Biol 146:27-17

Pochon X, Pawlowski J, Zaninetti L, Rowan R (2001) High genetic diversity and relative specificity among Symbiodinium-like endosymbiotic dinoflagellates in soritid foraminiferans. Mar Biol 139:1069-1078

Pochon X, Garcia-Cuetos L, Baker AC, Castella E, Pawlowski J (2007) One-year survey of a single Micronesian reef reveals extraordinarily rich diversity of Symbiodinium types in soritid foraminifera. Coral Reefs 26:867-882

Pochon X, Takabayashi M, Chasqui L, Chauka LJ, Logan DDK, Gates RD (2010) Comparison of endosymbiotic and free-living Symbiodinium (dinophyceae) diversity in a Hawaiian reef environment. J Phycol 46:53-65 
Porto I, Granados C, Restrepo JC, Sanchez JA (2008) Macroalgal-associated dinoflagellates belonging to the genus Symbiodinium in Caribbean reefs. PLoS ONE 3:e2160 [doi:10.1371/journal.pone.0002160]

Posada D (2008) jModelTest: phylogenetic model averaging. Mol Biol Evol 25:1253-1256

Ralph PJ, Gademann R, Larkum AWD (2001) Symbiodinium expelled from bleached corals at $33^{\circ} \mathrm{C}$ are photosynthetically competent. Mar Ecol Prog Ser 220:163-168

Rodriguez-Lanetty M (2003) Evolving lineages of Symbiodinium-like dinoflagellates based on ITS1 rDNA. Mol Phylogenet Evol 28:152-158

Rodriguez-Lanetty M, Cha H, Song JI (2002) Genetic diversity of symbiotic dinoflagellates associated with Anthozoans from Korean waters. 9th Int Coral Reef Symp 1:163-166

Rodriguez-Lanetty M, Loh W, Carter D, Hoegh-Guldberg O (2001) Latitudinal variability in symbiont specificity within the widespread scleractinian coral Plesiastrea versiopora. Mar Biol 138:1175-1181

Sampayo EM, Dove S, Lajeunesse TC (2009) Cohesive molecular genetic data delineate species diversity in the dinoflagellate genus Symbiodinium. Mol Ecol 18:500-519

Sampayo EM, Franceschinis L, Hoegh-Guldberg O, Dove S (2007) Niche partitioning of closely related symbiotic dinoflagellates. Mol Ecol 16:3721-3733

Santos SR, Taylor DJ, Kinzie RA, Hidaka M, Sakai K, Coffroth MA (2002) Molecular phylogeny of symbiotic dinoflagellates inferred from partial chloroplast large subunit (23S)-rDNA sequences. Mol Phylogenet Evol 23:97-111

Savage AM, Goodson MS, Visram S, Trapido-Rosenthal H, Wiedenmann J, Douglas AE (2002) Molecular diversity of symbiotic algae at the latitudinal margins of their distribution: dinoflagellates of the genus Symbiodinium in corals and sea anemones. Mar Ecol Prog Ser 244:17-26

Schonberg CHL, Suwa R, Hidaka M, Loh WKW (2008) Sponge and coral Symbiodinium in heat and light: preliminary results of photochemical efficiency monitored with pulse amplitude modulated fluorometry. Mar Ecol 29:247-258

Stat M, Carter D, Hoegh-Guldberg O (2006) The evolutionary history of Symbiodinium and scleractinian hosts-Symbiosis, diversity, and the effect of climate change. Perspect Plant Ecol Evol Syst 8:23-46

Steffan R, Goksoyr J, Bej AK, Atlas RM (1988) Recovery of DNA from soils and sediments. Appl Environ Microbiol 54 (12):2908-2915

Vidal R, Meneses I, Smith M (2002) Enhanced DNA extraction and PCR amplification of SSU ribosomal genes from crustose coralline algae. J Appl Phycol 14:223-227

Visram S, Douglas AE (2006) Molecular diversity of symbiotic algae (Symbiodinium) in scleractinian corals of Kenya. Coral Reefs 25:172-176

Wada S, Aoki MN, Tsuchiya Y, Sato T, Shinagawa H, Hama T (2007) Quantitative and qualitative analyses of dissolved organic matter released from Ecklonia cava Kjellman, in Oura Bay, Shimoda, Izu Peninsula, Japan. J Exp Mar Biol Ecol 349:344358

Wilkinson C (2004) Status of coral reefs of the world: 2004. Australian Institute of Marine Science, Townsville

Willis BL, Babcock RC, Harrison PL, Oliver JK (1985) Patterns in the mass spawning of corals on the Great Barrier Reef from 1981 to 1984. Proc 5th Int Coral Reef Symp 4: 343-348 
Table 1 Results of molecular analyses (PCRs, cloning and sequencing) for macroalgal and sediment samples. \#S: indicates the number of samples collected for each macroalga. \# Plates: numerals outside parenthesis indicate the number of cloning plates used for each macroalga; numerals within parenthesis indicate how many Symbiodinium sequences were found on each plate. Among 96 clones sequenced (24 plates*4 clones/plate), 21 were Symbiodinium. NSD indicates the number of non-Symbiodinium dinoflagellates found for each macroalga.

\begin{tabular}{llcccccl}
\hline $\begin{array}{l}\text { Macroalgal } \\
\text { Phyla }\end{array}$ & Macroalgae & \#S & \# Plates & & Isolates & Depth (m) & Sites \\
\hline Heron Island & & & & & & & \\
\hline Chlorophyta & Chlorodesmis fastigiata & 2 & $1(1)$ & 0 & Clade C & $0-4$ & Reef flat \\
Chlorophyta & Halimeda discoidea & 3 & $3(4,2,1)$ & 1 & Clade C & $0-4$ & Reef flat \\
Chlorophyta & Halimeda opuntia & 2 & $1(1)$ & 0 & Clade C & $5-11$ & 4 th Point \\
Cyanophyta & Cyanobacteria & 1 & $1(0)$ & 1 & - & $5-11$ & 4 th Point \\
Ochrophyta & Padina sp. & 2 & $2(1,0)$ & 0 & Clade C & $0-4$ & Reef flat \\
Rhodophyta & Porolithon onkodes & 4 & $3(0,0,0)$ & 5 & - & $0-2$ & Reef flat, 4th Pt. \\
Rhodophyta & Hypnea pannosa & 2 & $2(2,0)$ & 1 & Clade C & $0-4$ & Reef flat \\
Rhodophyta & Hypnea spinella & 1 & $1(1)$ & 0 & Clade C & $0-4$ & Reef flat \\
Rhodophyta & Laurencia intricata & 1 & $1(2)$ & 2 & Clade C & $0-4$ & Reef flat \\
Rhodophyta & Plocamium sp. & 1 & $1(0)$ & 0 & - & $5-11$ & 4 th Point \\
Mixed & Algal turfs & 4 & $2(1,1)$ & 2 & Clade C & $0-2$ & Reef flat \\
Mixed & Algal turfs & 1 & 0 & 0 & - & $5-11$ & 4th Point \\
- & Sediments & 2 & 0 & 1 & - & $0-4$ & Reef flat \\
\hline Keppel Islands & & & & & & \\
\hline Chlorophyta & Chlorodesmis fastigiata & 1 & 0 & 0 & - & $1-6$ & Middle I \\
Ochrophyta & Lobophora variegata & 3 & $1(1)$ & 2 & Clade C & $1-6$ & Middle I \\
Ochrophyta & Lobophora variegata & 1 & $1(1)$ & 0 & Clade C & 10 & Halfway I \\
Ochrophyta & Lobophora variegata & 1 & 0 & 0 & - & $0-3$ & Gt Keppel I \\
Rhodophyta & Asparagopsis taxiformis & 1 & $1(2)$ & 2 & Clade C & 10 & Halfway I \\
Rhodophyta & Peyssonnelia sp. & 1 & 0 & 0 & - & $0-3$ & Gt Keppel I \\
Mixed & Algal turfs & 1 & $1(0)$ & 0 & - & $0-3$ & Gt Keppel I \\
- & Sediments & 2 & $2(0,0)$ & 0 & - & 12 & Barren I \\
\hline
\end{tabular}


Table 2 List of Symbiodinium 28S-LSUrDNA sequences used in this study for phylogenetic

tree reconstruction. GBR: Great Barrier Reef, Australia; HI: Heron Island; LI: Lizard Island;

KI: Keppel Islands; OT: One Tree island; MB: Moreton Bay, Australia; FK: Florida Keys,

USA; Oki: Okinawa Island, Japan. MA: Massachusetts, USA.

\begin{tabular}{|c|c|c|c|c|c|}
\hline Strain & Source & Clade & Origin & Accession & Reference \\
\hline $\mathrm{Cx}$ & Cassiopea xamachana & A & Jamaica & AF427454 & Santos et al. (2002) \\
\hline Unspecified & Acropora longicyathus & A & GBR, OT & DQ981495 & Gomez-Cabrera et al. (2008) \\
\hline B1 & Nephthea sp. & B & GBR, HI & AF060892 & LaJeunesse et al. (2003) \\
\hline Pk13 & Plexaura kuna & $\mathrm{B}$ & FK & AF427458 & Santos et al. (2002) \\
\hline PurPflex & Plexaura flexuosa & $\mathrm{B}$ & FK & AF427460 & Santos et al. (2002) \\
\hline CG60 & Pavona divaricata & $\mathrm{C}$ & Guam & AJ308889 & Pochon et al. (2001) \\
\hline Ap7 & Acropora palifera & $\mathrm{C}$ & Oki & EU159441 & Schonberg et al. (2008) \\
\hline Gas 1.1 & Goniastrea aspera & $\mathrm{C}$ & MB & AY906989 & Unpublished \\
\hline Gt8 & Goniopora tenuidens & $\mathrm{C}$ & GBR, OT & DQ060732 & Loh et al. (1998) \\
\hline aga1 & Agaricia sp. & $\mathrm{C}$ & Bermuda & AY074938 & Savage et al. (2002) \\
\hline Am8 & Acropora millepora & $\mathrm{C}$ & GBR, OT & DQ060730 & Loh et al. (1998) \\
\hline Ag7 & Acropora glauca & $\mathrm{C}$ & MB & EF420766 & Unpublished \\
\hline Ag10 & Acropora glauca & $\mathrm{C}$ & MB & EF420765 & Unpublished \\
\hline Мc39 & Montastrea curta & $\mathrm{C}$ & MB & EF420771 & Unpublished \\
\hline KPC1 & Porites cylindrica & $\mathrm{C}$ & Kenya & AY588439 & Visram and Douglas (2006) \\
\hline C1 & Hard corals, anemones & $\mathrm{C}$ & GBR, HI & AY239384 & LaJeunesse et al. (2003) \\
\hline C1b & Pavona varians & $\mathrm{C}$ & GBR, HI & AY239385 & LaJeunesse et al. (2003) \\
\hline C3 & Hard corals, soft corals & $\mathrm{C}$ & GBR, HI & AY239386 & LaJeunesse et al. (2003) \\
\hline C15 & Hard corals, hydrozoa & $\mathrm{C}$ & GBR, HI & AY239387 & LaJeunesse et al. (2003) \\
\hline C17 & Montipora spp. & $\mathrm{C}$ & GBR, HI & AY239383 & LaJeunesse et al. (2003) \\
\hline C21 & Hard corals & $\mathrm{C}$ & GBR, HI & AY239382 & LaJeunesse et al. (2003) \\
\hline $\mathrm{C} 27$ & Pavona varians & $\mathrm{C}$ & GBR, HI & AY239381 & LaJeunesse et al. (2003) \\
\hline D1a & Hard corals, soft corals & $\mathrm{D}$ & GBR, HI & AF170149 & LaJeunesse et al. (2003) \\
\hline A024 & Acropora brueggemanni & $\mathrm{D}$ & Oki & AF396627 & Santos et al. (2002) \\
\hline P.di 1 & Pavona divaricata & $\mathrm{D}$ & Oki & AB248878 & Unpublished \\
\hline ССМР421 & Free Living & $\mathrm{E}$ & New Zealand & AY684264 & Santos et al. (2002) \\
\hline ССМР423 & Free Living & $\mathrm{E}$ & Falmouth MA & EF205004 & Moestrup and Daugbjerg (2007) \\
\hline LII41_1814x & Sorites sp. & $\mathrm{F}$ & GBR, LI & AJ830921 & Garcia-Cuetos et al. (2005) \\
\hline LII162_1935x & Amphisorus hemprichii & $\mathrm{F}$ & GBR, LI & AJ830918 & Garcia-Cuetos et al. (2005) \\
\hline FL34_1286x & Sorites sp. & $\mathrm{H}$ & FK & AJ621148 & Coffroth and Santos (2005) \\
\hline LII141_1914x & Sorites sp. & $\mathrm{H}$ & GBR, LI & AJ830907 & Garcia-Cuetos et al. (2005) \\
\hline Dc1 & Halimeda discoidea & $\mathrm{C}$ & GBR, HI & FJ851413 & This study \\
\hline Dc2 & Halimeda discoidea & $\mathrm{C}$ & GBR, HI & FJ851408 & This study \\
\hline Dc3 & Halimeda discoidea & $\mathrm{C}$ & GBR, HI & FJ851412 & This study \\
\hline Dc4 & Halimeda discoidea & $\mathrm{C}$ & GBR, HI & FJ851405 & This study \\
\hline Dc6 & Halimeda discoidea & $\mathrm{C}$ & GBR, HI & FJ851407 & This study \\
\hline Dc8 & Halimeda discoidea & $\mathrm{C}$ & GBR, HI & FJ851409 & This study \\
\hline Dc15 & Lobophora variegata & $\mathrm{C}$ & GBR, KI & FJ851411 & This study \\
\hline Dc21 & Padina sp. & $\mathrm{C}$ & GBR, HI & FJ851415 & This study \\
\hline Dc25 & Laurencia intricata & $\mathrm{C}$ & GBR, HI & FJ851416 & This study \\
\hline Dc27 & Laurencia intricata & $\mathrm{C}$ & GBR, HI & FJ851410 & This study \\
\hline Dc30 & Algal turfs & $\mathrm{C}$ & GBR, HI & FJ851414 & This study \\
\hline Dc54 & Algal turfs & $\mathrm{C}$ & GBR, HI & FJ851418 & This study \\
\hline Dc58 & Hypnea pannosa & $\mathrm{C}$ & GBR, HI & FJ851421 & This study \\
\hline Dc60 & Hypnea pannosa & $\mathrm{C}$ & GBR, HI & FJ851417 & This study \\
\hline
\end{tabular}




\begin{tabular}{llllll} 
Dc68 & Hypnea spinella & C & GBR, HI & FJ851403 & This study \\
Dc70 & Asparagopsis taxiformis & C & GBR, KI & FJ851419 & This study \\
Dc72 & Asparagopsis taxiformis & C & GBR, KI & FJ851420 & This study \\
Dc82 & Chlorodesmis fastigiata & C & GBR, HI & FJ851406 & This study \\
Dc88 & Halimeda opuntia & C & GBR, HI & FJ851404 & This study \\
\hline
\end{tabular}


Table 3 List of Symbiodinium isolated from macroalgal microhabitats and their subclades (according to the phylogenetic analysis). Potential coral hosts are those of the most similar sequences found in the BLAST search $\left(^{*}\right)$ and those on which LaJeunesse et al. (2003) found the same subclades (underlined). Accession numbers of similar sequences isolated from potential coral hosts are shown. Samples Dc11 and Dc36 were not used in the phylogenetic analysis. HI: Heron Island; RF: Reef flat; KI: Keppel Islands. M: Middle Island; Hw: Halfway Island.

\begin{tabular}{|c|c|c|c|c|}
\hline Strain & Macroalgal host & Subclade & Site & Potential coral host \\
\hline Dc1 & Halimeda discoidea & Undetermined & HI, RF & Goniopora*, Pavona* (DQ060732, AJ308889) \\
\hline Dc2 & Halimeda discoidea & Undetermined & $\mathrm{HI}, \mathrm{RF}$ & Pavona* (AJ308889) \\
\hline Dc3 & Halimeda discoidea & Undetermined & $\mathrm{HI}, \mathrm{RF}$ & Pavona* (AJ308889) \\
\hline Dc4 & Halimeda discoidea & Undetermined & $\mathrm{HI}, \mathrm{RF}$ & Pavona* (AJ308889) \\
\hline Dc6 & Halimeda discoidea & Undetermined & $\mathrm{HI}, \mathrm{RF}$ & Pavona* (AJ308889) \\
\hline Dc8 & Halimeda discoidea & Undetermined & $\mathrm{HI}, \mathrm{RF}$ & Pavona* (AJ308889) \\
\hline Dc11 & Lobophora variegata & - & KI, M & $\begin{array}{l}\text { Montastrea*, Acropora* (EF420771, } \\
\text { EF420766) }\end{array}$ \\
\hline Dc15 & Lobophora variegata & Undetermined & KI, Hw & Goniastrea*, Pavona* (AY906989,AJ308889) \\
\hline Dc21 & Padina sp. & Undetermined & $\mathrm{HI}, \mathrm{RF}$ & Goniopora* (DQ060732) \\
\hline Dc25 & Laurencia intricata & C3 & HI, RF & 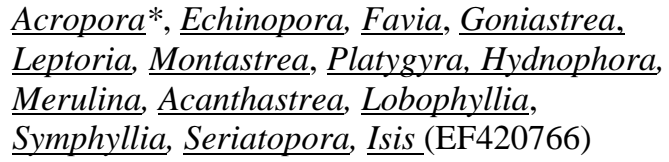 \\
\hline Dc27 & Laurencia intricata & Undetermined & HI, RF & Pavona* (AJ308889) \\
\hline Dc30 & Algal turfs & C17 & $\mathrm{HI}, \mathrm{RF}$ & Montipora, Goniopora* (DQ060732) \\
\hline Dc36 & Halimeda discoidea & - & $\mathrm{HI}, \mathrm{RF}$ & $\begin{array}{l}\text { Acropora*, Pavona*, Heliopora*, Ctenactis* } \\
\text { (EU159441, AJ308889, AJ308888, AJ308887) }\end{array}$ \\
\hline Dc54 & Algal turfs & $\mathrm{C} 3$ & $\mathrm{HI}, \mathrm{RF}$ & $\begin{array}{l}\text { Acropora* }{ }^{*} \text { Echinopora, Favia, Goniastrea, } \\
\text { Leptoria, Montastrea, } \text { Platygyra, Hydnophora, } \\
\text { Merulina, } \text { Acanthastrea, Lobophyllia, } \\
\text { Symphyllia, Seriatopora, Isis (EF420766) }\end{array}$ \\
\hline Dc58 & Hypnea pannosa & C15 & HI, RF & Porites ${ }^{*}$, Montipora (AY588439) \\
\hline Dc60 & Нурпеа рапnоsa & C3 & $\mathrm{HI}, \mathrm{RF}$ & 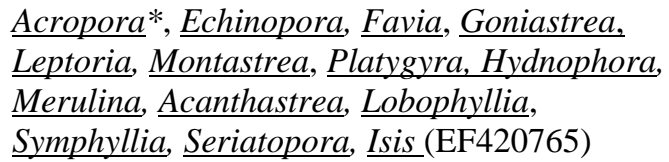 \\
\hline Dc68 & Hypnea spinella & Undetermined & HI, RF & $\begin{array}{l}\text { Acropora*, Heliofungia* (EU159441, } \\
\text { DQ060761) }\end{array}$ \\
\hline Dc70 & Asparagopsis taxiformis & $\mathrm{C} 3$ & $\mathrm{KI}, \mathrm{Hw}$ & $\begin{array}{l}\text { Acropora }{ }^{*}, \text { Echinopora, Favia, Goniastrea, } \\
\text { Leptoria, } \\
\text { Mentastrea, } \text { Platygyra, }, \text { Hydnophora, } \\
\text { Symphyllia, Seriatopora, Isis (DQ060730) }\end{array}$ \\
\hline Dc72 & Asparagopsis taxiformis & C3 & KI, Hw & 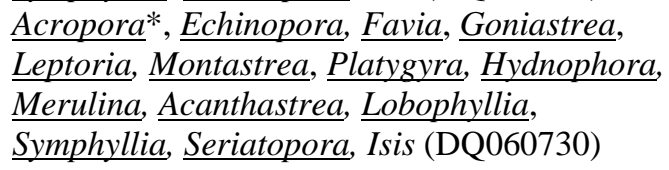 \\
\hline Dc82 & Chlorodesmis fastigiata & Undetermined & HI, RF & Pavona* (AJ308889) \\
\hline Dc88 & Halimeda opuntia & Undetermined & $\mathrm{HI}, 4^{\text {th }} \mathrm{pt}$ & Pavona* (AJ308889) \\
\hline
\end{tabular}




\section{Figure Legends}

Fig. 1 Location of study sites: a) Southern Great Barrier Reef, b) Heron Island and Keppel Islands. Specific collection sites are also shown around c) Keppel Islands and d) Heron Island. (Images modified from Google Earth()).

Fig. 2 Representative examples of macroalgae that were shown to harbour Symbiodinium spp. a) and b) Algal turfs from Heron Island, c) Asparagopsis taxiformis from Keppel Islands, d) Hypnea pannosa from Heron Island, e) Lobophora variegata from Keppel Islands, f) Padina sp. from Heron Island, g) Chlorodesmis fastigiata from Heron Island, h) Halimeda opuntia from Heron Island.

Fig. 3 Phylogenetic tree inferred by Maximum-Likelihood (ML) from the 28S-LSUrDNA of 19 macroalgal-associated Symbiodinium and 31 Symbiodinium reference sequences, downloaded from the GenBank. Clades, subclades and ML bootstrap values $>50 \%$ are indicated at their respective branches. Names of strains indicate their host/environmental origin. Colors next to macroalgal-associated strains indicate their macroalgal phyla (green macroalgae, red macroalgae or brown macroalgae). 

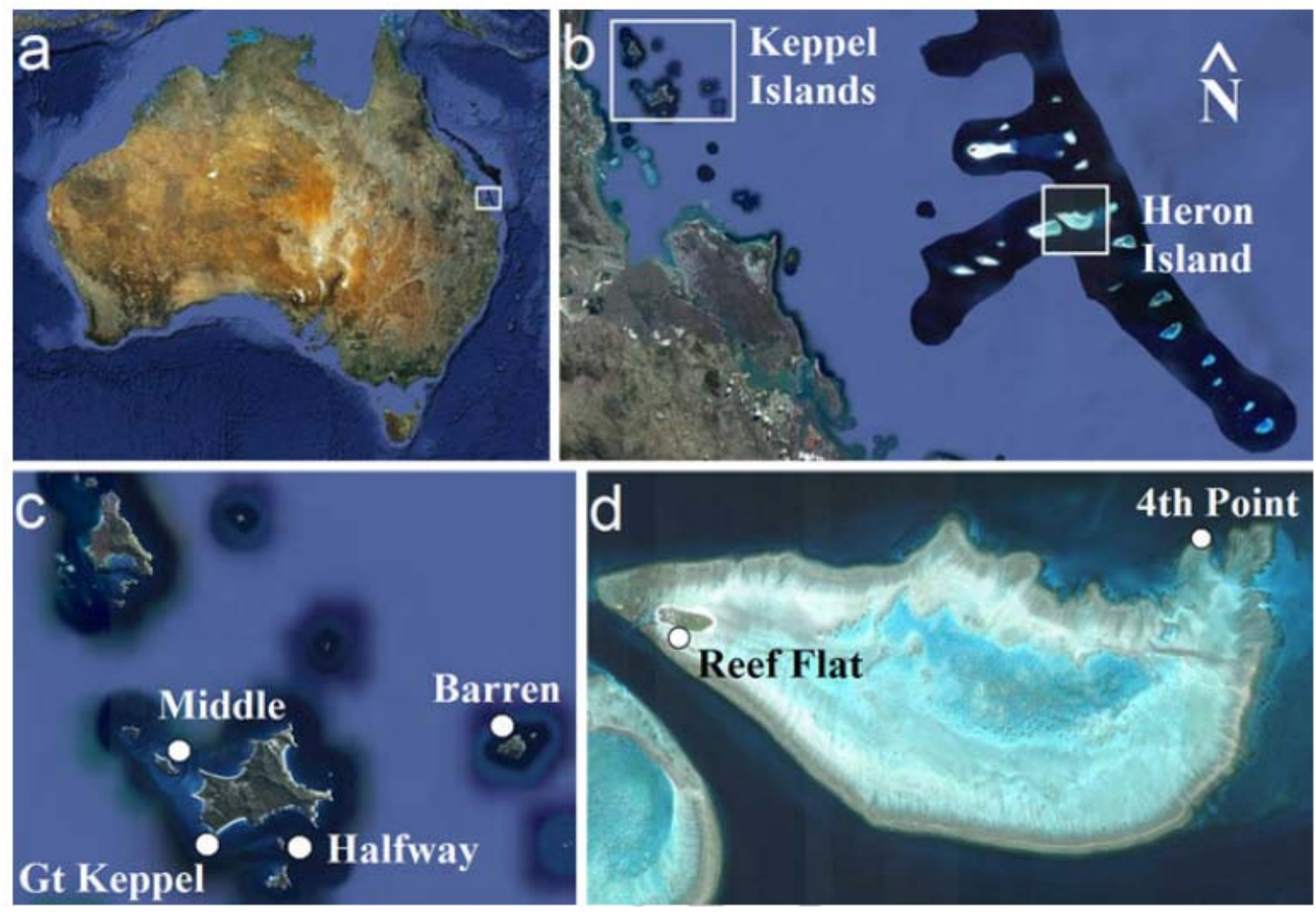

Fig 1. 

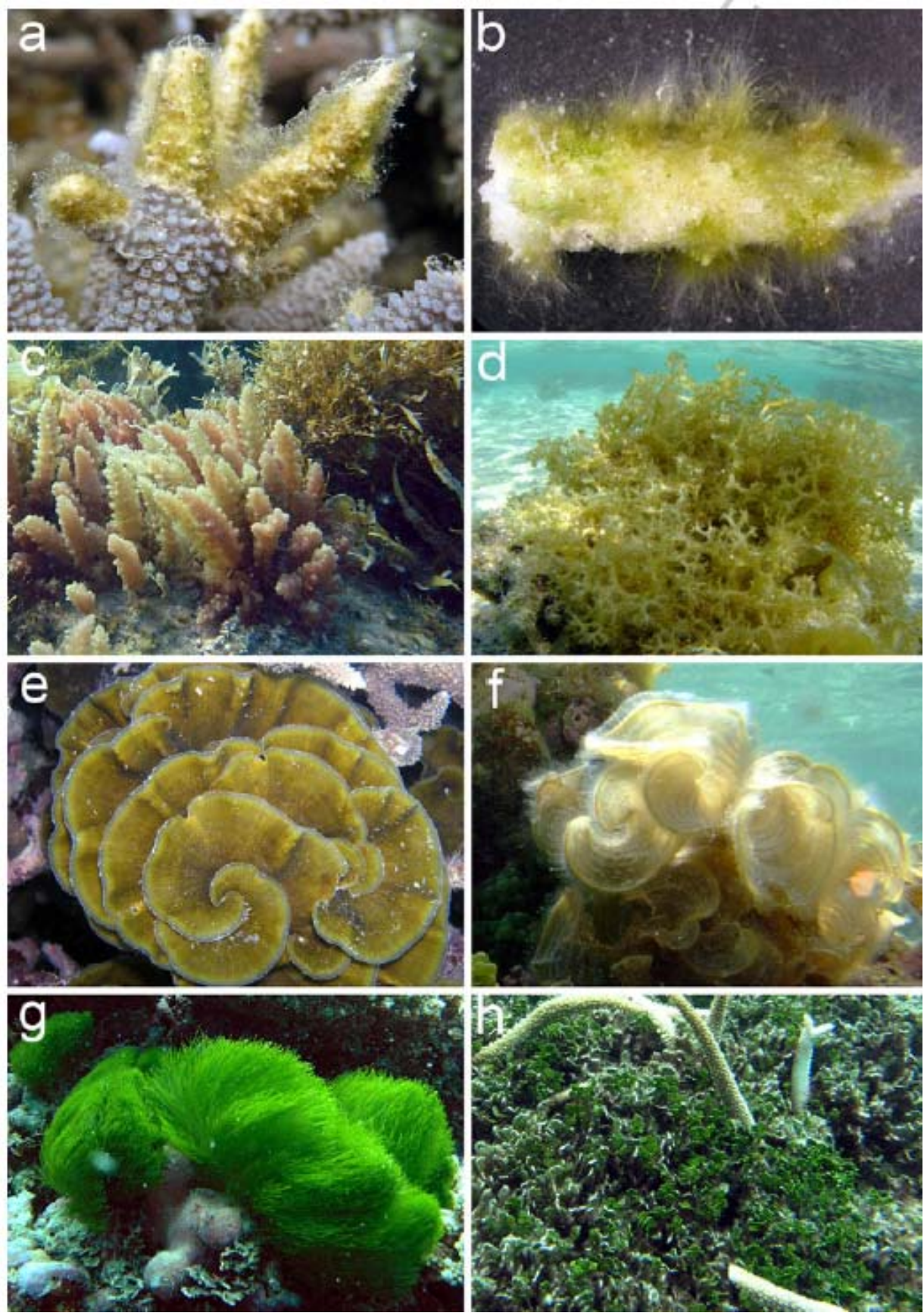

Fig 2. 


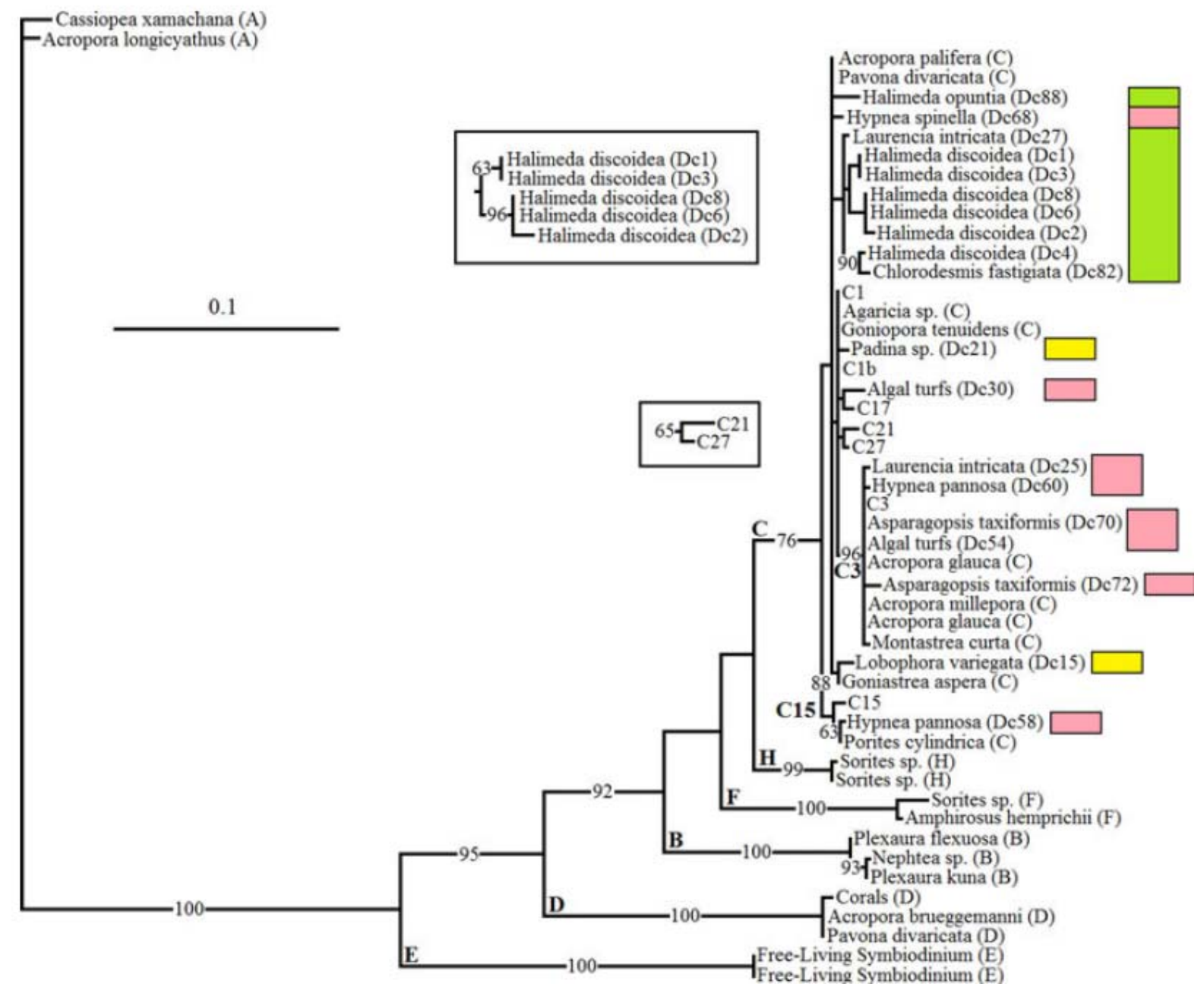

Fig 3. 